\title{
Pulmonary dysfunction in obese early adolescents
}

\author{
Bambang Supriyatno, Irma Sapriani, Sri Rezeki S. Hadinegoro \\ Department of Child Health, Medical School, University of Indonesia Cipto Mangunkusumo Hospital, Jakarta, Indonesia
}

\begin{abstract}
Abstrak
Tujuan Prevalensi obesitas pada anak mengalami peningkatan yang berarti di seluruh dunia. Obesitas dapat menyebabkan berbagai komplikasi, termasuk gangguan fungsi paru. Penelitian uji fungsi paru pada anak obes masih terbatas dan menunjukkan hasil yang berbeda-beda. Penelitian ini bertujuan mengetahui proporsi gangguan fungsi paru pada remaja obes dini di Indonesia serta hubungan antara derajat obesitas dan derajat gangguan fungsi paru.
\end{abstract}

Metode Uji potong lintang dilakukan di Departemen Ilmu Kesehatan Anak FKUI-RSCM pada bulan November 2007 sampai Desember 2008. Subjek adalah remaja berusia 10-12 tahun dengan obesitas. Pada subjek dilakukan uji fungsi paru untuk menilai FEV1/FVC, FEV1, FVC, V50, dan V25.

Hasil Terdapat 110 subjek yang memenuhi kriteria penelitian. Jenis kelamin lelaki sebanyak 83 (75,5\%) dan perempuan 27 (24,5\%); median IMT 26,7 (22,6-54,7) kg/m2, 92 subjek (83,6\%) superobes. Riwayat asma dan rinitis alergi terdapat pada 32 (29,1\%) dan 46 (41,8\%) subjek. Uji fungsi paru abnormal ditemukan pada 64 (58,2\%) subjek, terdiri dari gangguan paru campuran 33 (30\%), restriktif 28 (25,5\%), dan obstruktif 3 (2,7\%). Rerata nilai FEV1, FVC, V50, dan V25 mengalami penurunan, sedang rasio FEV1/FVC dalam batas normal. Tidak terdapat perbedaan bermakna rerata parameter uji fungsi paru pada kelompok superobes dan obes. Tidak ada korelasi antara IMT dengan parameter uji fungsi paru. Tidak terdapat hubungan antara derajat obesitas dengan derajat gangguan fungsi paru.

Kesimpulan Gangguan fungsi paru pada remaja dini obes 58,2\%. Kelainan tersering adalah tipe campuran (30\%), restriktif (25,5\%), dan obstruktif (2,7\%). Tidak ada korelasi antara IMT dan parameter uji fungsi paru. (Med $\boldsymbol{J}$ Indones 2010; 19: 179-84)

\begin{abstract}
Aim Obesity leads to various complications, including pulmonary dysfunction. Studies on pulmonary function of obese children are limited and the results are controversial. This study was aimed to determine proportion of pulmonary dysfunction on early adolescents with obesity and to evaluate correlation between obesity degree with pulmonary dysfunction degree.

Methods A cross-sectional study was conducted at the Department of Child Health, Medical School, University of Indonesia, from November 2007 to December 2008. Subjects were 10 to 12 year-old adolescents with obesity. Subjects underwent pulmonary function test (PFT) to assess FEV1/FVC, FEV1, FVC, V50, and V25.

Results 110 subjects fulfilled study criteria, 83 (75.5\%) were male and 27 (24.5\%) were female with median BMI $26.7(22.6-54.7) \mathrm{kg} / \mathrm{m} 2 ; 92$ subjects $(83.6 \%)$ were superobese. History of asthma and allergic rhinitis were found in 32 (29.1\%) and $46(41.8 \%)$ subjects, respectively. $64(58.2 \%)$ subjects had abnormal PFT results consisting of restrictive type in $28(25.5 \%)$ subjects, obstructive in 3 (2.7\%), and combined type in 33 (30\%). Mean FEV1, FVC, V50, and V25 values were below normal, while mean FEV1/FVC ratio was normal. There was no statistically significant correlation between BMI and PFT parameters. No significant correlation was found between degree of obesity and the severity of pulmonary dysfunction.

Conclusions Pulmonary dysfunction occurs in $58.2 \%$ obese early adolescents. The most common abnormality was combined type (30\%), followed by restrictive (25.5\%), and obstructive type (2.7\%). There was no correlation between $\mathrm{BMI}$ and pulmonary function test parameters. (Med J Indones 2010; 19: 179-84)
\end{abstract}

Key words: early adolescents, obesity, pulmonary function test

The prevalence of childhood obesity has been increasing worldwide, 2.3-3.3 fold in the United States and 2-2.8 fold in the United Kingdom during the past ten years. ${ }^{1,2}$ Meanwhile, the prevalence of childhood obesity in Jakarta in 1998 and 2007 were $9.6 \%$ and $15.3 \%$, respectively., ${ }^{3,4}$ Obesity may lead to various complications, including pulmonary function abnormalities and obstructive sleep apnea syndrome Correspondence email to: bangsupri@yahoo.com
(OSAS). ${ }^{5,6}$ The effects of obesity on pulmonary function in adults has been well-documented. The most common abnormalities in obese adults are decreased expiratory flow rates and lung volumes. ${ }^{7-9}$

Pulmonary function test (PFT) studies in obese children and adolescents are limited and the results are inconsistent. ${ }^{6}$ Various studies reported different findings 
in PFT in obese children. Some reported normal while other study showed low basal PFT parameters in obese children. ${ }^{10-12} \mathrm{Li} \mathrm{AM}$ et $a l^{6}$ reported that reduction of functional residual capacity and diffusion impairment as the most common abnormalities. Ulger et $a l^{13}$ stated that a strong negative correlation between anthropometric measurements and PFT parameters were found. Body mass index (BMI) is an important determinant of reduced spirometric parameters. ${ }^{1}$

The aims of this study were to determine the prevalence of pulmonary function abnormalities in Indonesian obese early adolescents and to evaluate the relationship between degree of obesity and the severity of pulmonary function abnormality.

\section{METHODS}

Cross sectional study was conducted at the Department of Child Health, Medical School, University of Indonesia, during November 2007 to December 2008. Children aged 10-12 years with obesity (BMI for age and sex $\geq$ $\mathrm{P}_{95}$ according to CDC-NCHS 2000 growth chart) were enrolled consecutively from 10 elementary schools in Jakarta. Subjects with craniofacial disproportion and exacerbation of asthma were excluded. This study was a part of the larger study entitled "Obstructive Sleep Apnea Syndrome Risk Factors in Early Adolescents with Obesity: Scoring System for Diagnostic Prediction". ${ }^{15}$ Ethical clearance was approved by the Ethics Committee, Medical School, University of Indonesia. Informed consent from the parents of all subjects were obtained at the time of enrollment.

Sample size was calculated based on the formula for proportion estimation for single sample. The minimum sample size required was 96 subjects, using 10\% absolute precision, 5\% level of significance, and $46 \%$ as proportion of PFT abnormality in previous study. ${ }^{6}$ One hundred and ten subjects had fulfilled the inclusion criteria.

Subjects were recruited from 10 elementary schools. Information regarding obesity and its effects on pulmonary function had been given to the parents. Weight (kilograms) and standing height (centimeter) were measured by a calibrated weighing scale and stadiometer, using standard anthropometric techniques. Body mass index was calculated as weight $(\mathrm{kg}) /$ height squared $\left(\mathrm{m}^{2}\right)$. Children who have BMI $\geq$ P95 CDCNCHS 2000 growth chart were defined as obese, while those with BMI $\geq$ P97 were superobese. All subjects underwent PFT and questionnaire about demographic data, history of asthma and, allergic rhinitis taken from the parents.

\section{Pulmonary function test}

Pulmonary function test of forced vital capacity (FVC) maneuvers was measured by PS7 spirometer according to Polgar standard procedure. The best of at least three technically appropriate measurements for forced expiratory volume in one second $\left(\mathrm{FEV}_{1}\right)$, forced vital capacity (FVC), FEV1/FVC, and maximum expiratory flow if $50 \%$ and $25 \%$ of the $\mathrm{FVC}$ remaining in the lung ( $\mathrm{V}_{50}$ and $\mathrm{V}_{25}$, respectively) were recorded. Restrictive type was defined as decreased FVC below $80 \%$ of the predicted values; obstructive type as decreased $\mathrm{FEV}_{1}$ below $80 \%$ of the predicted values; and combined type as decreased of both FVC and $\mathrm{FEV}_{1}$ below $80 \%$ of the predicted values. The severity of pulmonary function abnormalities were classified as mild (70-79\%), moderate $(60-69 \%)$, and severe $(<60 \%)$. Thus, the subjects were dided in 3 categories, 1)mild obstructive and/or restrictive type; 2)moderate obstructive and/ or restrictive type; and 3) severe obstructive and/or restrictive type.

\section{Statistical analysis}

Statistical analysis wes performed using the Statistical Package for the Social Sciences (SPSS) version 17.0 software. Normality of data was tested by KolmogorovSmirnov test. Student's t-test was used to compare means of normally distributed pulmonary function test variables and Mann-Whitney test if the distribution of variables were abnormal. Spearman's rank correlation coefficient was used to assess correlation between body mass index and pulmonary function test variables $\left(\mathrm{FEV}_{1}, \mathrm{FVC}, \mathrm{FEV}_{1} / \mathrm{FVC}, \mathrm{V}_{50}, \mathrm{~V}_{25}\right)$. The association between degree of obesity and the severity of pulmonary function abnormalities was analyzed by non-parametric test (Kolmogorov-Smirnov test). For all analyses, $p$ values of $<0.05$ regarded as statistically significant.

\section{RESULTS}

There were 110 obese adolescents enrolled in this study with male predominance. Characteristics of study subjects are presented on Table 1 . The median weight was $55.0 \mathrm{~kg}$ (range 38.0-116.0), mean height was 144.4 $\mathrm{cm}$ (SD 8.3), and median BMI was $26.7 \mathrm{~kg} / \mathrm{m}^{2}$ (range 
22.6-54.7). Most subjects were superobese (83.6\%), $29.1 \%$ and $41.8 \%$ of subjects had history of asthma and allergic rhinitis, respectively.

Table 1. Characteristics of subjects

\begin{tabular}{lcc}
\hline \multicolumn{1}{c}{ Characteristics } & N=110 & Percentage (\%) \\
\hline Age (years) & 66 & 60.0 \\
10 & 34 & 30.9 \\
11 & 10 & 9.1 \\
12 & & \\
Sex $\quad$ Male & 83 & 75.5 \\
$\quad$ Female & 27 & 24.5 \\
Severity of obesity & 92 & 83.6 \\
$\quad$ Superobese $(\geq \mathrm{P} 97)$ & 18 & 16.4 \\
$\quad$ Obese $(\geq \mathrm{P} 95)$ & & \\
History of asthma & 32 & 29.1 \\
$\quad$ Yes & 78 & 70.9 \\
$\quad$ No & & \\
History of allergic rhinitis & 46 & 58.2 \\
$\quad$ Yes & 64 & \\
$\quad$ No & & \\
\hline
\end{tabular}

Sixty four (58.2\%) subjects had abnormal pulmonary function. Combined type was found in 33 subjects (30\%), restrictive type in $28(25.5 \%)$, and obstructive type in 3 (2.7\%). Mean $\mathrm{FEV}_{1}, \mathrm{FVC}, \mathrm{V}_{50}$ and $\mathrm{V}_{25}$ were below normal, but the mean $\mathrm{FEV} 1 / \mathrm{FVC}$ ratio was normal. The mean values of all PFT variables, except FVC, in subjects with history of asthma were lower than those of subjects without history of asthma $(p<0.05)$. Pulmonary function test variables did not differ significantly between subjects with and without history of allergic rhinitis.

Table 2 compares PFT parameters in obese and superobese groups. Mean FEV 1 and FVC in the superobese group was lower than in the obese group, but the difference was statistically insignificant. The types of pulmonary function abnormalities were similar in both groups (Table 3). Combined type was the most common abnormality.

The relationship between degree of obesity and the severity of pulmonary function abnormalities were evaluated by determining the correlation between BMI and PFT parameters (Table 4) and the association between degree of obesity and the degree of pulmonary function abnormalities (Table 5). We did not find any correlation between BMI and PFT variables. There was no association between degree of obesity and degree of pulmonary function abnormalities $(\mathrm{p}=1.000)$.

Table 2. Pulmonary function test parameters in obese and superobese groups

\begin{tabular}{ccccc}
\hline $\begin{array}{c}\text { Pulmonary function test } \\
\text { Parameters }\end{array}$ & $\begin{array}{c}\text { Superobese } \\
(\mathrm{n}=92)\end{array}$ & $\begin{array}{c}\text { Obese } \\
(\mathrm{n}=18)\end{array}$ & $\begin{array}{c}\text { Total } \\
(\mathrm{n}=110)\end{array}$ & $\mathrm{p}$ \\
\hline $\mathrm{FEV}_{1} / \mathrm{FVC}(\%)(\mathrm{SD})$ & 90.73 & 88.85 & 90.42 & \\
& $(5.49)$ & $(6.26)$ & $(5.64)$ & $0.240 *$ \\
$\mathrm{FEV}_{1}(\%)(\mathrm{SD})$ & 78.84 & 80.57 & 79.13 & \\
& $(13.04)$ & $(15.03)$ & $(13.32)$ & 0.617 \\
$\mathrm{FVC}(\%)(\mathrm{SD})$ & 75.58 & 79.18 & 76.17 & \\
& $(12.98)$ & $(14.08)$ & $(13.17)$ & 0.291 \\
$\mathrm{~V}_{50}(\%)(\mathrm{SD})$ & 80.37 & 78.36 & 80.04 & \\
& $(21.53)$ & $(24.38)$ & $(21.92)$ & 0.724 \\
$\mathrm{~V}_{25}(\%)(\mathrm{SD})$ & 76.78 & 73.46 & 76.24 & 0.563 \\
& $(22.62)$ & $(19.84)$ & $(22.14)$ & \\
\hline
\end{tabular}

*Mann-Whitney test

Table 3. Pulmonary function abnormalities and degree of obesity

\begin{tabular}{|c|c|c|c|c|c|}
\hline \multirow{2}{*}{$\begin{array}{l}\text { Degree of } \\
\text { obesity }\end{array}$} & \multicolumn{5}{|c|}{ Pulmonary function test } \\
\hline & & Abnormal & & Normal & Total \\
\hline \multirow[t]{2}{*}{ Superobese } & 28 & 24 & 2 & 38 & 92 \\
\hline & $(30.43 \%)$ & $(26.09 \%)$ & $(2.17 \%)$ & $(41.30 \%)$ & $(100 \%)$ \\
\hline \multirow[t]{2}{*}{ Obese } & 5 & 4 & 1 & 8 & 18 \\
\hline & $(27.78 \%)$ & $(22.22 \%)$ & $(5.55 \%)$ & $(44.44 \%)$ & $(100 \%)$ \\
\hline \multirow[t]{2}{*}{ Total } & 33 & 28 & 3 & 46 & 110 \\
\hline & $(30.00 \%)$ & $(25.45 \%)$ & $(2.73 \%)$ & $(41.82 \%)$ & $(100 \%)$ \\
\hline
\end{tabular}

Table 4. Correlation between body mass index and pulmonary function test parameters

\begin{tabular}{lcc}
\hline PFT parameters & $\mathrm{r}$ & $\mathrm{P}$ \\
\hline $\mathrm{FEV}_{1} / \mathrm{FVC}(\%)$ & -0.046 & 0.636 \\
$\mathrm{FEV}_{1}(\%)$ & -0.055 & 0.571 \\
$\mathrm{FVC}(\%)$ & -0.057 & 0.558 \\
$\mathrm{~V}_{50}(\%)$ & -0.070 & 0.468 \\
$\mathrm{~V}_{25}(\%)$ & -0.045 & 0.641 \\
\hline
\end{tabular}

Table 5. Association between degree of obesity and degree of pulmonary function abnormalities

\begin{tabular}{lccccc}
\hline \multirow{2}{*}{ Degree of obesity } & \multicolumn{3}{c}{$\begin{array}{c}\text { Pulmonary function } \\
\text { abnormalities }\end{array}$} & Total & p* \\
\cline { 2 - 5 } & $\begin{array}{c}\text { mild } \\
{[\mathrm{n}(\%)]}\end{array}$ & $\begin{array}{c}\text { moderate } \\
{[\mathrm{n}(\%)]}\end{array}$ & $\begin{array}{c}\text { severe } \\
{[\mathrm{n}(\%)]}\end{array}$ & \\
\hline Superobese & $22(40.7)$ & $21(38.9)$ & $11(20.4)$ & $54(100)$ & 1.000 \\
Obese & $4(40.0)$ & $4(40.0)$ & $2(20.0)$ & $10(100)$ & \\
Total & $26(40.6)$ & $25(39.1)$ & $13(20.3)$ & $64(100)$ & \\
\hline
\end{tabular}

*Kolmogorov-Smirnov test 


\section{DISCUSSION}

Our study found that the proportion of pulmonary function abnormalities in obese early adolescents was $58.2 \%$. Similarly, Li et $a l^{6}$ reported that the most common abnormalities found were reduction of functional residual capacity (46\%) and impairment of diffusion capacity (33\%). Ulger et $\mathrm{al}^{13}$ compared basal PFT parameters of 38 obese children, aged 9 to 15 years, with that of 30 healthy children, and found that basal PFT parameters (FVC, FEV1, PEF, FEF25-75) in healthy children were normal (above $100 \%$ of predicted value). Interestingly, we found that the most common disorder was combined obstructive and restrictive type (30\%). Obesity may lead to restrictive disorder through mechanical effects. Excess body fat distribution within the abdominal cavity and chest wall directly compresses the thoracic cage, diaphragm, and lung resulting in decreased lung and chest wall compliance and elastic recoil. ${ }^{9,16}$ There are two possibilities explaining combined disorder as the most frequent abnormality. First, most subjects (83\%) are superobese (BMI $\geq$ P97) whose obstructive disorders are likely attributed to fat infiltration in the upper airway soft tissues. Second, a positive history of atopy in $30-40 \%$ subjects may contribute to obstructive components of combined disorders. We excluded subjects with history of asthma in subgroup analysis and found that proportion of lung function abnormality was $53.9 \%$.

Some previous studies have reported the association between atopy and obesity. ${ }^{14,17-21}$ Increased BMI related to increased airway resistance was a strong independent risk factor for asthma (OR 2.17, 95\%CI $1.22-3.87, \mathrm{p}=0.009)$ and atopy (OR 2.06, 95\%CI 1.32-3.22, $\mathrm{p}=0.002) .{ }^{14,17}$ Chow et all ${ }^{18}$ reported that childhood obesity is associated with increased airway inflammation. There are some evidences that obesity is a proinflammatory state, with increased leptin and proinflammatory cytokines such as interleukin-6, interleukin-1, and tumor necrosis factor- $\alpha$ (TNF- $\alpha$ ), which upregulate airway inflammation..$^{22}$ It seems that there is co-expression of the genes for asthma and obesity. Genes which may have a role in controlling both conditions include those encoding $\beta 2$ adrenergic receptors, TNF- $\alpha$, and insulin growth factor 1 (IGF-1). ${ }^{23,24}$ In this study, we found that PFT parameters in subjects with history of asthma were lower than those without. This finding may support the association between obesity and asthma, but further studies are needed to confirm this hypothesis.

The effect of obesity on pulmonary function has been well-studied in adults, but studies in children have been limited and have inconsistent results. In this study, mean $\mathrm{FEV}_{1}, \mathrm{FVC}, \mathrm{V}_{50}$, and $\mathrm{V}_{25}$ were decreased, while mean FEV1/FVC ratio was normal. Consistent with our study, Ulger $e{ }^{a} l^{13}$ reported that basal respiratory function test parameters $\left(\mathrm{FEV}_{1}, \mathrm{FVC}, \mathrm{PEF}, \mathrm{FEF}_{25-75}\right)$ were lower in obese children compared to those of a control group, but the $\mathrm{FEV}_{1} / \mathrm{FVC}$ ratio was similar. Li AM et $a l^{6}$ found that the most common abnormalities were reduction of functional residual capacity and impairment of diffusion capacity. Diffusion impairment may reflect intrinsic changes in the lungs including lipid deposition, cell hyperplasia, alveolar enlargement, and decreased of alveolar surface area. The median values of FEV1 and $\mathrm{FVC}$ were normal, while median $\mathrm{FEV} 1 / \mathrm{FVC}$ ratio below the normal limit 83\% (IQR 78-87\%). ${ }^{6}$

Spathopoulos et $a l^{14}$ reported that PFT parameters (FEV1, FVC, $\mathrm{FEF}_{25-75}$ and FEV1/FVC) were decreased in overweight and obese children. Airway narrowing characterized by reduction of $\mathrm{FEF}_{25-75}(7.5 \%)$ and FEV1 (5\%) was more marked compared to FVC reduction $(2.5 \%)$. This may be explained by extrinsic mechanical compression due to fat accumulation which causes decreased chest wall recoil and compliance, resulting in expiratory volume reduction. Nevertheless, a mechanical effect was not the only factor, since pulmonary function parameters were not different between overweight and obese children. ${ }^{14}$

Boran et $a l^{10}$ found that PFT parameters of mildly obese children were similar to those of the normal weight children. Only three out of 80 children had obstructive abnormalities on their pulmonary function tests. We suggested that these different findings were due to different degree of obesity between Boran's subjects and ours. The majority of our subjects were superobese, in whom pulmonary function abnormalities could be clearly seen.

The mean $\mathrm{FEV}_{1}$ and $\mathrm{FVC}$ values were lower in superobese compared to those of obese group in this study, although the difference was not statistically significant. These results might be explained by the fact that we did not compare obese adolescents to a control group and because the proportion of superobese subjects was larger than that of obese subjects making it difficult to find a difference.

This study failed to find any correlation between BMI and PFT parameters. The result was consistent when subjects with history of asthma were excluded in subgroup analysis. Tantisira et $a l^{25}$ found that increased 
BMI was associated with decrement in the $\mathrm{FEV}_{1} / \mathrm{FVC}$ ratio, and an increase of 5 units BMI was associated with a decrease in $\mathrm{FEV}_{1} / \mathrm{FVC}$ of over $1 \%$. Tantisira included mostly well-nourished children in the study $(70.8 \%)$, the remainder being overweight and obese children. Ulger et $a l^{13}$ reported a strong negative correlations between BMI, relative weight, skinfold thickness, waist-to-hip circumference ratio and basal $\mathrm{FVC}, \mathrm{FEV}_{1}$, and PEF values.

Li AM et $a l^{6}$ found a significant negative correlation between degree of functional residual capacity (FRC) with degree of obesity assessed by dual energy x-ray absorptiometry (DEXA) scan, but the correlation was not found when using BMI as the indicator of obesity. DEXA scan is more accurate and objective to assess total body fat than BMI or other antropometric measurements. ${ }^{26}$ Boran et $a l^{10}$ reported similar results to our study that there was no correlation between pulmonary function parameters and anthropometric measurements. This strengthens the possibility that anthropometric parameters including BMI cannot reflect body fat distribution accurately. Eventhough DEXA remains a more valid indicator of obesity, it still has some limitations, such as high cost, impracticality, and risk of radiation exposure. Conflicting results in previous studies may be caused by the use of different indicators of obesity (BMI, relative weight, skinfold thickness, waist-to-hip circumference ratio, DEXA scan), varying sample sizes, and presence or absence of a control group.

To present the association between degree of obesity with the severity of pulmonary dysfunction, subjects classified as having mild, moderate, or severe pulmonary function abnormalities. In superobese and obese groups, mild and moderate pulmonary dysfunction were most common. We did not find any correlation between degree of obesity and pulmonary dysfunction severity. This finding may be explained by the great disproportion between superobese and obese group (1:5) in our study.

This study has some limitations. First, it was a cross sectional study with only a single PFT measurement. A longitudinal study is needed to evaluate the effects of BMI changes on pulmonary function over time. Second, we did not recruit adolescents with normal BMI as a control group. A comparison between obese and control group will be better in detecting correlation between BMI and PFT parameters. Third, history of asthma and allergic rhinitis was based on a short questionnaire and not confirmed by objective measurements such as response to bronchodilators, total $\mathrm{IgE}$ levels, and skin prick test.

From the above study, it can be concluded that pulmonary function abnormalities are present in early adolescents with obesity. The most common abnormality found is combined restrictive and obstructive type. There is no correlation between BMI and PFT parameters. Further studies are needed to evaluate association between degree of obesity and pulmonary fuction abnormalities using more valid measurements of body fat distribution and including normal subjects as control group.

\section{REFERENCES}

1. World Health Organization. Obesity: preventing and managing the global epidemic: report of a WHO consultation. Geneva: The Office of Publication, World Health Organization; 1999.

2. Batch JA, Baur LA. Management and prevention of obesity and its complications in children and adolescents. Med J Austr. 2005;182:130-5.

3. Djer MM. Prevalence of obesity and its influencing factors of school children in Kenari 7 and 8 elementary school, Jakarta [thesis]. Jakarta: University of Indonesia; 1998.

4. Susanti TE. Prevalence and risk factors of obesity in school children aged 10-12 years in 5 areas of DKI Jakarta [thesis]. Jakarta: university of Indonesia; 2007.

5. de Sousa AGP, Cercato C, Mancini MC, Halpern A. Obesity and obstructive sleep apnea-hypopnea syndrome. Obes Rev. 2008;9:340-54.

6. Li AM, Chan D, Wong E, Yin J, Nelson EAS, Fok TF. The effects of obesity on pulmonary function. Arch Dis Child. 2003;88:361-3.

7. Ferreti A, Giampicollo P, Cavalli A, Millic-Emili J, Tantucci C. Expiratory flow limitation and orthopnea in massively obese subjects. Chest. 2001;119:1401-8.

8. King GG, Brown NJ, Diba C, Thorpe CW, Munoz P, Marks $\mathrm{GB}$, et al. The effects of body weight on airway caliber. Eur Respir J. 2005;25:896-901.

9. Koenig SM. Pulmonary complications of obesity. Am J Med Sci. 2001;321:249-79.

10. Boran P, Tokuc G, Pisgin B, Oktem S, Yegin Z, Boston O. Impact of obesity on ventilatory function. J Pediatr (Rio J). 2007;83:171-6.

11. Inselman LS, Milanese A, Deurloo A. Effect of obesity on pulmonary function in children. Pediatr Pulmonol. 1993;16:130-7.

12. Marcus CL, Curtis S, Koerner CB, Joffe A, Serwint JR, Loughlin GM. Evaluation of pulmonary function and polysomnography in obese children and adolescents. Pediatr Pulmonol. 1996;21:176-83.

13. Ulger Z, Demir E, Tanac R, Goksen D, Gulen F, Darcan $\mathrm{S}$, et al. The effect of childhood obesity on respiratory 
function tests and airway hyperesponsiveness. Turk J Pediatr. 2006;48:43-50.

14. Spathopoulos D, Paraskakis E, Trypsianis G, Tsalkidis A, Arvanitidou V, Emporiadou M, et al. The effect of obesity on pulmonary lung function of school aged children in Greece. Pediatr Pulmonol. 2009;44:273-80.

15. Supriyatno BS. Obstructive sleep apnea syndrome risk factor in early adolescents with obesity: scoring system for diagnostic prediction [dissertation]. Jakarta: University of Indonesia; 2009.

16. Jubber AS. Respiratory complications of obesity. Int J Clin Pract. 2004;58:573-80.

17. Amra B, Rahmani A, Salimi S, Mohammadzadeh Z, Golshan M. Association between asthma and body mass index in children. Iran J Allergy Asthma Immunol. 2005;4:33-7.

18. Chow JSW, Leung ASM, Li WWS, Tse TPK, Sy HK, Leung TF. Airway inflammatory and spirometric measurements in obese children. Hong Kong Med J. 2009;15:364-52.

19. El Helaly N, Kamel Y, Elaziz EA, Elwan A, Nabih M. Childhood obesity and asthma severity: is there a link? J Biol Sci. 2009;9:259-63.

20. von Mutius E, Schwartz J, Neas LM, Dockery D, Weiss ST. Relation of body mass index to asthma and atopy in children: the National health and nutrition examination study III. Thorax. 2001;56:835-8.

21. Wickens K, Barry D, Fiezema A, Rhodius D, Bone M, Purdie G, et al. Obesity and asthma in 11-12 years old New Zealand in 1989 and 2000. Thorax. 2005;60:7-12.

22. Weiss ST. Obesity: insight into the origins of asthma. Nat Immunol. 2005;6:537-9.

23. Garenc C, Perusse L, Chagnon YC, Rankinen T, Gagnon J, Borecki IB, et al. Effects of beta2-adrenergic receptor gene variants on adiposity: the HERITAGE Family Study. Obes Res. 2003;11:612-8.

24. Matricardi PM, Gruber C, Wahn U, Lau S. The asthmaobesity link in childhood: open questions, complex evidence, a few answers only. Clin Exp Allergy. 2007;37:476-84.

25. Tantisira KG, Litanjua AA, Weiss ST, Fuhlbrigge AL. Association of body mass with pulmonary function in the childhood asthma management program (CAMP). Thorax. 2003;58:1036-41.

26. Goran MI. Measurement issues related to studies of childhood obesity: assessment of body composition, body fat distribution, physical activity, and food intake. Pediarics. 1998;101:505-18. 